\begin{tabular}{|c|c|c|c|}
\hline \multirow{2}{*}{$\begin{array}{r}\text { Case Reports in } \\
\text { Gastroenterology }\end{array}$} & \multicolumn{2}{|c|}{ Case Rep Gastroenterol 2016;10:366-372 } & \multirow[b]{2}{*}{$\begin{array}{l}\text { Karger } \\
\text { Open access }\end{array}$} \\
\hline & $\begin{array}{l}\text { DOI: 10.1159/000447423 } \\
\text { Publisned onine: Jury ZU, } 2016\end{array}$ & $\begin{array}{l}\text { (c) } 2016 \text { The Author(s) } \\
\text { Published by S. Karger AG, Basel } \\
\text { www.karger.com/crg }\end{array}$ & \\
\hline & $\begin{array}{l}\text { This article is licensed under } \\
\text { International License (CC BY-N } \\
\text { Usage and distribution for comm }\end{array}$ & $\begin{array}{l}\text { nons Attribution-NonCommercia } \\
\text { ger.com/Services/OpenAccessLice } \\
\text { uires written permission. }\end{array}$ & \\
\hline
\end{tabular}

\title{
Successful Management of Graft Reinfection of HCV Genotype 2 in Living Donor Liver Transplantation from a Hepatitis B Core Antibody- Positive Donor with Sofosbuvir and Ribavirin
}

\author{
Reina Sasaki ${ }^{a} \quad$ Tatsuo Kanda $^{a} \quad$ Masayuki Ohtsuka ${ }^{b}$ Shin Yasui ${ }^{a}$ \\ Yuki Haga ${ }^{a}$ Masato Nakamura ${ }^{a}$ Masayuki Yokoyama ${ }^{a}$ Shuang $\mathrm{Wu}^{\mathrm{a}}$ \\ Shingo Nakamoto ${ }^{a}$ Makoto Arai ${ }^{a}$ Hitoshi Maruyama ${ }^{a}$ \\ Masaru Miyazaki ${ }^{b}$ Osamu Yokosuka ${ }^{b}$ \\ a Department of Gastroenterology and Nephrology, Graduate School of Medicine, Chiba \\ University, Chiba, Japan; ${ }^{b}$ Department of General Surgery, Graduate School of Medicine, \\ Chiba University, Chiba, Japan
}

\section{Keywords}

Hepatitis C virus · Direct-acting antivirals · Living donor liver transplantation · Sofosbuvir

\begin{abstract}
Direct-acting antivirals (DAAs) are relatively safe and highly effective for the eradication of hepatitis $\mathrm{C}$ virus $(\mathrm{HCV})$ in liver transplant recipients. In this case study, we present a female with a graft reinfected with HCV genotype 2 who was treated with a combination of sofosbuvir and ribavirin after living donor liver transplantation (LDLT). Because the graft was from a hepatitis $B$ core antibody-positive donor, passive immunization with hyperimmune hepatitis $B$ immunoglobulin ( $\mathrm{HBIG}$ ) and entecavir were also provided to prevent hepatitis $B$ virus (HBV) reactivation. It became clear that the combination of sofosbuvir and ribavirin promptly led to a sustained virologic response and that this combination was safe to treat graft reinfection with HCV genotype 2 after LDLT. Adverse events caused by DAAs were not observed,
\end{abstract}


except for slight anemia. HBIG and entecavir were useful in the prevention of HBV reactivation. In conclusion, the present case indicated that DAA treatment for graft reinfection with HCV is safe and effective in LDLT from hepatitis B core antibody-positive donors.

\author{
(c) 2016 The Author(s) \\ Published by S. Karger AG, Basel
}

\title{
Introduction
}

Hepatitis $\mathrm{C}$ virus (HCV) infection is a leading cause of end-stage liver disease and hepatocellular carcinoma $[1,2]$. HCV-related liver disease is the most common indication for orthotopic liver transplantation in the USA and Northern Europe and for living donor liver transplantation (LDLT) in Japan [3-5]. Unfortunately, liver transplantation is not a cure for $\mathrm{HCV}$ infection, and the occurrence of graft reinfection with HCV is universal, leading to progression of liver fibrosis and occasionally to graft loss at rates higher than in transplant patients not infected with HCV $[5,6]$.

In Japan, because of long-standing legal difficulties associated with cadaveric donation [7], LDLT is the main type of liver transplantation for end-stage liver disease. Infection with $\mathrm{HCV}$ is of negative predictive value in LDLT [8]. The sustained virologic response (SVR) rate was $\sim 40 \%$ in donors of LDLT treated with pegylated interferon (peginterferon) plus ribavirin [9], although adverse events were commonly observed even in nontransplanted patients receiving this treatment [10]. Akamatsu et al. [9] reported that the dose reduction rate and the discontinuation rate of peginterferon plus ribavirin treatment was 40 and $42 \%$, respectively.

Recent progress in the development of direct-acting antivirals (DAAs) against HCV has made it possible to eradicate HCV effectively and to shorten the treatment duration compared to the previous standard of care, i.e. peginterferon plus ribavirin [10]. Treatment with the HCV NS5B polymerase inhibitor sofosbuvir plus ribavirin for 12 weeks was shown to lead to high rates of SVR ( 97\%) in Japanese patients infected with chronic HCV genotype 2 [11].

Asian-Pacific countries, including Japan, account for $\sim 50 \%$ of all chronic hepatitis B virus (HBV) infection globally [12]. Given the prevalence of HBV, LDLT from hepatitis B core antibody-positive donors to recipients was occasionally performed with passive immunization with hyperimmune hepatitis B immunoglobulin (HBIG) plus nucleos(t)ide analogs [13].

Here, we report on an LDLT recipient who was reinfected with HCV genotype 2a after receiving a graft from a hepatitis B core antibody-positive donor. HCV genotype 2 a was eradicated by a 12-week treatment with sofosbuvir plus ribavirin with HBIG plus entecavir, one of the nucleos(t)ide analogs, for the successful prevention of HBV reappearance.

\section{Case Report}

A 66-year-old Japanese woman developed liver failure due to cirrhosis and HCV genotype 2a infection. She was a treatment-naïve patient, but her IL28B rs8099917 was a favorable genotype (TT). Two years prior to LDLT, she has been diagnosed with liver cirrhosis due to HCV infection without liver biopsy. She had been infected with HCV after having received a blood transfusion during childbirth at the age of 30 years. At LDLT, she had peripheral edema with a MELD (Model for End-Stage Liver Disease) score of 12. LDLT with a right liver graft from a hepatitis B core antibody-positive donor was performed in February 2015. 
Five months after LDLT, the HCV RNA level was $5.8 \mathrm{log} \mathrm{IU} / \mathrm{ml}$, and she was diagnosed with graft reinfection with HCV genotype 2a. Combination treatment with $400 \mathrm{mg}$ daily of sofosbuvir and $400 \mathrm{mg}$ daily of ribavirin was commenced. Her height, body weight, and body mass index were $1.56 \mathrm{~m}, 50 \mathrm{~kg}$, and 20.5, respectively. She abstained from consumption of alcohol. Her laboratory data before treatment are shown in table 1. The HCV RNA level before treatment was $5.8 \mathrm{log} \mathrm{IU} / \mathrm{ml}$. After LDLT, she received triple immunosuppressive therapy consisting of tacrolimus ( $3 \mathrm{mg}$ daily), mycophenolate mofetil, and basiliximab with passive immunization with HBIG and $0.5 \mathrm{mg}$ daily of entecavir.

Four weeks after initiating the combination treatment with sofosbuvir and ribavirin, HCV RNA levels were undetectable. She completed this treatment for 12 weeks and achieved SVR at 24 weeks following the termination of this treatment (SVR24) (fig. 1). There was no evidence of $\mathrm{HBV}$ reactivation.

Because her hemoglobin level was $12.2 \mathrm{~g} / \mathrm{dl}$ before the commencement of this treatment, an oral iron preparation was also started. After 2 months of treatment, her hemoglobin level fell to $10.8 \mathrm{mg} / \mathrm{dl}$. Then, the dose of ribavirin was decreased to $200 \mathrm{mg}$ daily, and her hemoglobin level improved to $12.8 \mathrm{~g} / \mathrm{dl}$ (fig. 1). During this period of treatment, she did not develop evidence of bone marrow suppression, such as observed in peginterferon-plusribavirin treatment. No serious adverse events were observed. During treatment, the trough level of tacrolimus remained stable.

\section{Discussion}

We presented a female patient with living donor-related graft reinfection with HCV genotype $2 \mathrm{a}$ who was treated with a combination of sofosbuvir and ribavirin for 12 weeks. Although several DAAs have drug-drug interactions, no changes in this patient's drug protocol, which included immunosuppressants and combination treatment of sofosbuvir plus ribavirin, were necessary in this case.

Treatment of HCV infection after liver transplantation is a challenge. Peginterferon plus ribavirin with or without DAAs may be attempted, but the use of peginterferon is restricted by severe side effects and inadequate efficacy [5]. In addition, interferon has an immunemediated cytotoxicity, occasionally causing allograft dysfunction [14]. Interferon-free therapy is a viable treatment option and improves treatment efficacy [15-20]. This case suggests that DAAs are well tolerated and effective for the eradication of HCV from post-liver transplantation patients.

In the present case of LDLT, graft reinfection with HCV genotype 2 was treated with a combination of sofosbuvir plus ribavirin. The patient achieved SVR24, although she had anemia as an adverse event, and anti-HCV treatment was continued without blood transfusion. Curry et al. [17] reported that common adverse events of combination treatment with sofosbuvir and ribavirin were fatigue (in $38 \%$ of patients), headache $(23 \%)$, and anemia (21\%) after liver transplantation. Charlton et al. [18] reported that the most common adverse events were fatigue (30\%), diarrhea (28\%), headache $(25 \%)$, and anemia $(20 \%)$ during a 24-week combination treatment course of sofosbuvir plus ribavirin after liver transplantation.

In the present study, the patient received a liver graft from a hepatitis B core antibodypositive donor, and, in general, $\mathrm{HBV}$ from these donors is transmitted to recipients at a high rate [13]. Therefore, passive immunization with HBIG plus treatment with entecavir were provided to prevent HBV reactivation. Curing HCV infection with DAAs in HBV/HCV coinfec- 
tion and monitoring for HBV reactivation should be performed [21], because DAAs against HCV do not have any effect on HBV replication, unlike interferon. In the present case, the patient was treated with HBIG and entecavir, and there was no evidence of HBV reactivation.

Recently, more effective regimens with DAAs against HCV have been reported [22, 23]. These regimens may make it possible to shorten the duration of treatment and to make it easier to achieve SVR. The use of interferon-free regimens is possible for the eradication of HCV in post-LDLT patients with grafts from hepatitis B core antibody-positive donors, as was demonstrated by our patient, who was successfully treated with HBIG and entecavir to prevent $\mathrm{HBV}$ reactivation. In conclusion, 12 -week treatment with sofosbuvir plus ribavirin is relatively safe and highly effective for the eradication of HCV genotype 2 in LDLT patients.

\section{Acknowledgements}

We thank all colleagues at the liver units of their hospitals who cared for the patients described herein.

\section{Statement of Ethics}

The authors have no ethical conflicts to disclosure.

\section{Disclosure Statement}

Tatsuo Kanda and Osamu Yokosuka received lecture fees from Gilead Sciences. The other authors declare that there is no conflict of interest regarding the publication of this manuscript.

\section{References}

1 Armstrong GL, Alter MJ, McQuillan GM, Margolis HS: The past incidence of hepatitis C virus infection: implications for the future burden of chronic liver disease in the United States. Hepatology 2000;31:777-782.

2 El-Serag HB: Epidemiology of viral hepatitis and hepatocellular carcinoma. Gastroenterology 2012;142:1264-1273.

3 Organ Procurement and Transplantation Network: 2012 Annual Data Report. http://srtr.transplant.hrsa.gov/annual_reports/2012/Default.aspx (accessed on February 7, 2016).

4 Guillouche P, Féray C: Systematic review: anti-viral therapy of recurrent hepatitis C after liver transplantation. Aliment Pharmacol Ther 2011;33:163-174.

-5 Kaneko J, Sugawara Y, Yamaguchi T, Harada N, Akamatsu N, Ishizawa T, Aoki T, Sakamoto Y, Hasegawa K, Tamura S, Tanaka T, Kokudo N: Telaprevir-based triple therapy for hepatitis C null responders among living donor liver transplant recipients. Biosci Trends 2014;8:339-345.

-6 Berenguer M, Prieto M, Rayón JM, Mora J, Pastor M, Ortiz V, Carrasco D, San Juan F, Burgueño MD, Mir J, Berenguer J: Natural history of clinically compensated hepatitis $C$ virus-related graft cirrhosis after liver transplantation. Hepatology 2000;32:852-858.

7 Kanda T, Yokosuka O, Ehata T, Maru Y, Imazeki F, Saisho H, Shiratori Y, Omata M: Detection of GBV-C RNA in patients with non-A-E fulminant hepatitis by reverse-transcription polymerase chain reaction. Hepatology 1997;25:1261-1265.

8 Kawaguchi Y, Sugawara Y, Akamatsu N, Kaneko J, Hamada T, Tanaka T, Ishizawa T, Tamura S, Aoki T, Sakamoto Y, Hasegawa K, Kokudo N: Impact of early reoperation following living-donor liver transplantation on graft survival. PLoS One 2014;9:e109731. 


\section{Case Reports in \\ Gastroenterology}

Case Rep Gastroenterol 2016;10:366-372 $10.1159 / 000447423$

C 2016 The Author(s). Published by S. Karger AG, Basel www.karger.com/crg

Sasaki et al: Successful Management of Graft Reinfection of HCV Genotype 2 in LDLT from a Hepatitis B Core Antibody-Positive Donor with Sofosbuvir and Ribavirin

-9 Akamatsu N, Sugawara Y, Kokudo N, Eguchi S, Fujiwara T, Ohdan H, Nagano H, Taketomi A, Kitagawa Y, Shimada M, Ku Y, Yanaga K, Shirabe K, Ikegami T, Mizokami M, Takeuchi M, Maehara Y: Outcomes of living donor liver transplantation for hepatitis $\mathrm{C}$ virus-positive recipients in Japan: results of a nationwide survey. Transpl Int 2014;27:767-774.

10 Kanda T, Imazeki F, Yokosuka O: New antiviral therapies for chronic hepatitis C. Hepatol Int 2010;4:548-561.

11 Omata M, Nishiguchi S, Ueno Y, Mochizuki H, Izumi N, Ikeda F, Toyoda H, Yokosuka O, Nirei K, Genda T, Umemura T, Takehara T, Sakamoto N, Nishigaki Y, Nakane K, Toda N, Ide T, Yanase M, Hino K, Gao B, Garrison KL, Dvory-Sobol H, Ishizaki A, Omote M, Brainard D, Knox S, Symonds WT, McHutchison JG, Yatsuhashi H, Mizokami M: Sofosbuvir plus ribavirin in Japanese patients with chronic genotype $2 \mathrm{HCV}$ infection: an open-label, phase 3 trial. J Viral Hepat 2014;21:762-768.

12 Sarin SK, Kumar M, Lau GK, Abbas Z, Chan HL, Chen CJ, Chen DS, Chen HL, Chen PJ, Chien RN, Dokmeci AK, Gane E, Hou JL, Jafri W, Jia J, Kim JH, Lai CL, Lee HC, Lim SG, Liu CJ, Locarnini S, Al Mahtab M, Mohamed R, Omata M, Park J, Piratvisuth T, Sharma BC, Sollano J, Wang FS, Wei L, Yuen MF, Zheng SS, Kao JH: Asian-Pacific clinical practice guidelines on the management of hepatitis B: a 2015 update. Hepatol Int 2016;10:1-98.

13 Uemoto S, Sugiyama K, Marusawa H, Inomata Y, Asonuma K, Egawa H, Kiuchi T, Miyake Y, Tanaka K, Chiba T: Transmission of hepatitis B virus from hepatitis B core antibody-positive donors in living related liver transplants. Transplantation 1998;65:494-499.

14 Ikegami T, Yoshizumi T, Yoshida Y, Kurihara T, Harimoto N, Itoh S, Shimokawa M, Fukuhara T, Shirabe $\mathrm{K}$, Maehara Y: Telaprevir versus simeprevir for the treatment of recurrent hepatitis $\mathrm{C}$ after living donor liver transplantation. Hepatol Res 2016;46:E136-E145.

15 Fontana RJ, Hughes EA, Bifano M, Appelman H, Dimitrova D, Hindes R, Symonds WT: Sofosbuvir and daclatasvir combination therapy in a liver transplant recipient with severe recurrent cholestatic hepatitis C. Am J Transplant 2013;13:1601-1605.

16 Kim B, Trivedi A, Thung SN, Grewal P: Case report of successful treatment of fibrosing cholestatic hepatitis $C$ with sofosbuvir and ribavirin after liver transplantation. Semin Liver Dis 2014;34:108-112.

17 Curry MP, Forns X, Chung RT, Terrault NA, Brown R Jr, Fenkel JM, Gordon F, O’Leary J, Kuo A, Schiano T, Everson G, Schiff E, Befeler A, Gane E, Saab S, McHutchison JG, Subramanian GM, Symonds WT, Denning J, McNair L, Arterburn S, Svarovskaia E, Moonka D, Afdhal N: Sofosbuvir and ribavirin prevent recurrence of HCV infection after liver transplantation: an open-label study. Gastroenterology 2015;148:100-107.

18 Charlton M, Gane E, Manns MP, Brown RS Jr, Curry MP, Kwo PY, Fontana RJ, Gilroy R, Teperman L, Muir AJ, McHutchison JG, Symonds WT, Brainard D, Kirby B, Dvory-Sobol H, Denning J, Arterburn S, Samuel D, Forns X, Terrault NA: Sofosbuvir and ribavirin for treatment of compensated recurrent hepatitis C virus infection after liver transplantation. Gastroenterology 2015;148:108-117.

19 Ueda Y, Kaido T, Hatano E, Ohtsuru S, Uemoto S: Safe and effective treatment with daclatasvir and asunaprevir in a liver transplant recipient with severe cholestatic hepatitis C. Hepatol Res 2015;45:1360-1362.

20 Kawaoka T, Imamura M, Morio K, Nakamura Y, Tsuge M, Nelson Hayes C, Kawakami Y, Aikata H, Ochi H, Ishiyama $\mathrm{K}$, Ide $\mathrm{K}$, Tashiro $\mathrm{H}$, Ohdan $\mathrm{H}$, Chayama $\mathrm{K}$ : Three patients treated with daclatasvir and asunaprevir for recurrent hepatitis C after liver transplantation: case report. Hepatol Res 2016;46:707712.

21 Collins JM, Raphael KL, Terry C, Cartwright EJ, Pillai A, Anania FA, Farley MM: Hepatitis B virus reactivation during successful treatment of hepatitis $C$ virus with sofosbuvir and simeprevir. Clin Infect Dis 2015;61:1304-1306.

22 Curry MP, O’Leary JG, Bzowej N, Muir AJ, Korenblat KM, Fenkel JM, Reddy KR, Lawitz E, Flamm SL, Schiano T, Teperman L, Fontana R, Schiff E, Fried M, Doehle B, An D, McNally J, Osinusi A, Brainard DM, McHutchison JG, Brown RS Jr, Charlton M; ASTRAL-4 Investigators: Sofosbuvir and velpatasvir for HCV in patients with decompensated cirrhosis. N Engl J Med 2015;373:2618-2628.

-23 Foster GR, Afdhal N, Roberts SK, Bräu N, Gane EJ, Pianko S, Lawitz E, Thompson A, Shiffman ML, Cooper C, Towner WJ, Conway B, Ruane P, Bourlière M, Asselah T, Berg T, Zeuzem S, Rosenberg W, Agarwal K, Stedman CA, Mo H, Dvory-Sobol H, Han L, Wang J, McNally J, Osinusi A, Brainard DM, McHutchison JG, Mazzotta F, Tran TT, Gordon SC, Patel K, Reau N, Mangia A, Sulkowski M; ASTRAL-2 Investigators; ASTRAL-3 Investigators: Sofosbuvir and velpatasvir for HCV genotype 2 and 3 infection. N Engl J Med 2015;373:2608-2617. 


\section{Case Reports in Gastroenterology

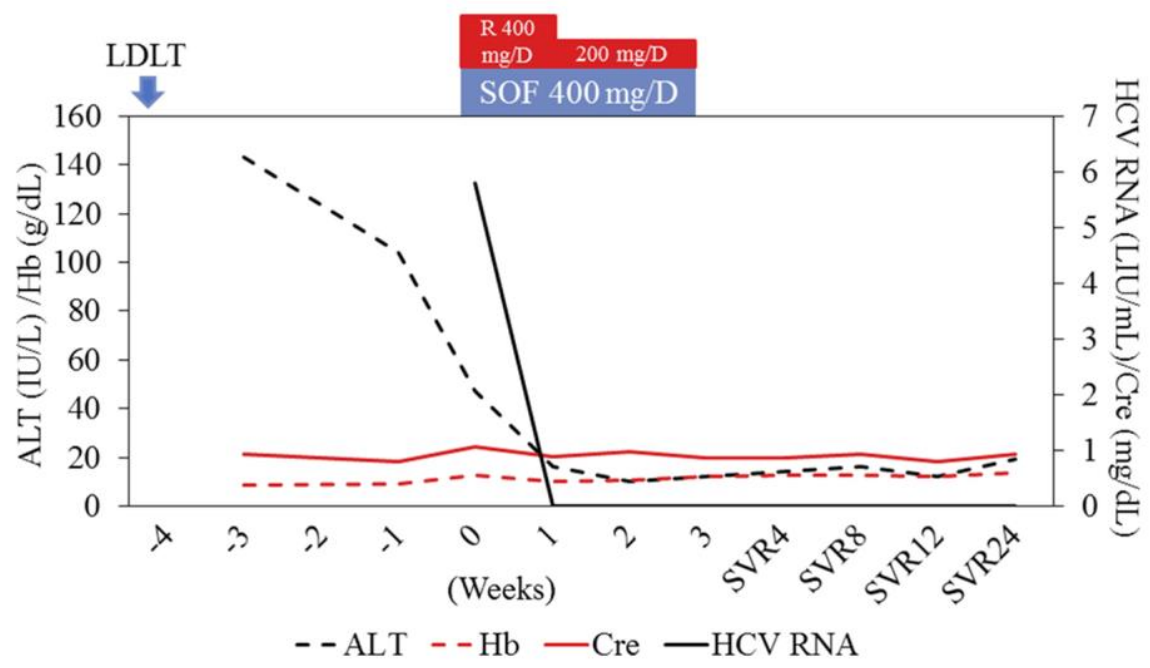

Fig. 1. Clinical course of the patient in the present study. SVR4, SVR8, SVR12, and SVR24 denote SVRs at 4, 8, 12 and 24 weeks, respectively. ALT = Alanine transaminase; Cre = creatinine; $\mathrm{Hb}=$ hemoglobin; LDLT = living donor liver transplantation; $\mathrm{R}=$ ribavirin; $\mathrm{SOF}=$ sofosbuvir. 
Sasaki et al.: Successful Management of Graft Reinfection of HCV Genotype 2 in LDLT from a Hepatitis B Core Antibody-Positive Donor with Sofosbuvir and Ribavirin

Table 1. Laboratory findings before the commencement of the combination treatment with sofosbuvir and ribavirin in the present case

\begin{tabular}{lcll}
\hline Item & Value & Item & Value \\
\hline AST & $74 \mathrm{IU} / \mathrm{l}$ & WBC & $2,500 / \mu \mathrm{l}$ \\
ALT & $61 \mathrm{IU} / \mathrm{l}$ & RBC & $362 \times 10^{4} / \mu \mathrm{l}$ \\
$\mathrm{LDH}$ & $223 \mathrm{IU} / \mathrm{l}$ & Hemoglobin & $12.2 \mathrm{~g} / \mathrm{dl}$ \\
ALP & $525 \mathrm{IU} / \mathrm{l}$ & Hematocrit & $35.6 \%$ \\
$\gamma$-GTP & $40 \mathrm{IU} / \mathrm{l}$ & Platelets & $12.1 \times 10^{4} / \mu \mathrm{l}$ \\
T.BIL & $0.5 \mathrm{mg} / \mathrm{dl}$ & PT & $120 \%$ \\
D.BIL & $0.1 \mathrm{mg} / \mathrm{dl}$ & PT-INR & 0.96 \\
TP & $6.5 \mathrm{~g} / \mathrm{dl}$ & Anti-HCV & positive \\
Alb & $4.0 \mathrm{~g} / \mathrm{dl}$ & HCV RNA & 5.8 log IU $/ \mathrm{ml}$ \\
T.CHO & $156 \mathrm{mg} / \mathrm{dl}$ & HCV genotype & 2 a \\
UA & $6.0 \mathrm{mg} / \mathrm{dl}$ & HBsAg & negative \\
UN & $23 \mathrm{mg} / \mathrm{dl}$ & Anti-HBs & positive \\
Cre & $1.12 \mathrm{mg} / \mathrm{dl}$ & HBV DNA & negative \\
eGFR & $38.1 \mathrm{ml} / \mathrm{min} / 1.73 \mathrm{~m}^{2}$ & Anti-HIV & negative \\
\hline
\end{tabular}

AST = Aspartate aminotransferase; ALT = alanine transaminase; $\mathrm{LDH}=$ lactate dehydrogenase; ALP = alkaline phosphatase; $\gamma$-GTP $=\gamma$ glutamyltransferase; T.BIL = total bilirubin; D.BIL = direct bilirubin; $\mathrm{TP}=$ total protein; $\mathrm{Alb}=$ albumin; $\mathrm{T} . \mathrm{CHO}=$ total cholesterol; $\mathrm{UA}=$ uric acid; UN = urea nitrogen; Cre = creatinine; eGFR = estimated glomerular filtration rate; $\mathrm{WBC}=$ white blood cell count; $\mathrm{RBC}=$ red blood cell count; $\mathrm{PT}=$ prothrombin time; $\mathrm{PT}-\mathrm{INR}=\mathrm{PT}$ international normalized ratio; anti-HCV = anti-hepatitis $\mathrm{C}$ virus antibody; HBsAg = hepatitis $\mathrm{B}$ virus surface antigen; anti-HBs = anti-hepatitis B virus surface antibody; anti-HIV = anti-human immunodeficiency virus antibody. 